\title{
PENGARUH SUBSTITUSI PASIR POZZOLAN SEBAGAI AGREGAT HALUS TERHADAP KUAT TEKAN BETON PASCA BAKAR DENGAN DAN TANPA PERENDAMAN
}

\author{
Syarifah Asria Nanda ${ }^{1)}$, David Sarana ${ }^{2)}$, M. Zainul Yaqin ${ }^{3)}$ \\ Jurusan Teknik Sipil Universitas Malikussaleh \\ Email:syarifah_nanda@yahoo.com ${ }^{1)}$ davidsarana82@gmail.com ${ }^{2}$
}

DOI: http://dx.doi.org/10.29103/ti.v8i2.162

\begin{abstract}
Abstrak
Salah satu kegagalan konstruksi beton kebakaran pada konstruksi, hal ini mempengaruhi kualitas/kekuatan struktur beton. Beton mutu tinggi merupakan beton dengan kuat tekan lebih besar dari 41,4 Mpa. Pasir pozzolan dihasilkan dari alam hasil sedimentasi gunung berapi yang mengandung senyawa silika dan alumina seperti yang terkandung di dalam semen. Penelitian ini bertujuan untuk mengetahui berapa besar mutu kuat tekan beton pasca bakar dengan dan tanpa perendaman. Obyek dalam penelitian ini adalah beton segar menggunakan pasir pozzolan $10 \%$ sebagai pengganti sebagian agregat halus menggunakan superplasticizer $1,5 \%$ dari berat semen. Jumlah sampel pada penelitian ini 50 buah, 25 sampel Beton Normal dan 25 sampel Beton Pozzolan. Pengujian kuat tekan beton normal dan pasca bakar tanpa perendaman dilakukan pada umur 28 hari, sedangkan pada beton pasca bakar dengan perendaman dilakukan setelah 42 hari perendaman. Dari hasil penelitian diperoleh kuat tekan beton optimum mengunakan substitusi pasir pozzolan pasca bakar $200^{\circ} \mathrm{C}$ dengan perendaman sebesar 45,10 Mpa, sedangkan mutu beton yang terendah terdapat pada beton pasca bakar $400^{\circ} \mathrm{C}$ tanpa perendaman sebesar 31,97 Mpa. Penggunaan substitusi pasir pozzolan sebagai agregat halus terhadap beton pasca bakar dengan dan tanpa perendaman dapat meningkatkan mutu beton yang dibakar dengan suhu $200^{\circ} \mathrm{C}$ dan $400^{\circ} \mathrm{C}$ dibandingkan dengan beton normal pada perlakuan yang sama.
\end{abstract}

Kata kunci: Pozzolan, Kuat Tekan Beton, Pasca Bakar, Perendaman.

\begin{abstract}
One of the failures in the concrete construction is when fire occurs in the construction that will affect to the quality / the strength of the concrete structure. High quality concrete is a concrete with a compressive strength greater than $41.4 \mathrm{Mpa}$. Pozzolanic sand is produced from nature that is from the results of volcanic sedimentation containing silica and alumina compounds as contained in cement. This study aims to determine how much the quality of compressive strength concrete after burned with and without immersion. The object of this study was fresh concrete using $10 \%$ pozzolan sand as a substitute for a portion of fine aggregate, and using superplasticizer $1.5 \%$ of the weight of cement. The samples in this study were 50 pieces; 25 samples of Normal Concrete and 25 samples of Concrete Pozzolan. The testing of compressive strength for normal concrete and post-burn concrete without immersion was carried out at the age of 28 days, while in post-burn concrete with immersion carried out after 42 days of immersion. From the results of the study obtained optimum compressive strength concrete using sand substitution pozzolan post combustion $200^{\circ} \mathrm{C}$ with immersion is $45.10 \mathrm{Mpa}$, while the lowest quality of concrete found in post-burn concrete $400^{\circ} \mathrm{C}$ without immersion of $31.97 \mathrm{Mpa}$. The use of pozzolan sand substitution as fine aggregate for post-burn concrete with and without immersion can improve the quality of concrete burned at temperatures of $200^{\circ} \mathrm{C}$ and $400^{\circ} \mathrm{C}$ compared to normal concrete at the same treatment.
\end{abstract}

Keywords: Pozzolan, Concrete Press Strength, Post-Burn, Immersion

Pengaruh Substitusi Pasir Pozzolan Sebagai Agregat Halus Terhadap Kuat Tekan Beton Pasca Bakar Dengan Dan Tanpa Perendaman - Syarifah Asria Nanda, David Sarana, M. Zainul Yaqin 


\section{Latar Belakang}

Salah satu kegagalan pada struktur konstruksi beton adalah saat terjadi kebakaran pada konstruksi tersebut, hal ini akan mengakibatkan terjadinya peningkatan suhu tinggi secara siknifikan yang akan mengakibatkan perubahan mendasar dari sifat-sifat struktur beton. Pada kondisi ini struktur konstruksi mengalami penurunan kemampuan untuk mendukung beban yang ada, bahkan pada kondisi tertentu konstruksi beton tidak mampu lagi mendukung beban yang bekerja dan dipastikan konstruksi tidak dapat lagi digunakan atau dimanfaatkan sebagaimana fungsi awal konstruksi beton tersebut. Pada peristiwa kebakaran terjadinya perubahan temperatur yang cukup tinggi, peristiwa tersebut akan berpengaruh terhadap elemen-elemen struktur beton. Pada proses tersebut akan terjadi suatu siklus pemanasan dan pendinginan yang bergantian, yang akan menyebabkan adanya perubahan fase fisis dan kimiawi secara kompleks. Hal ini akan mempengaruhi kualitas/kekuatan struktur beton tersebut.

Beton mutu tinggi kadang-kadang disebut dengan nama lain beton kinerja tinggi karena memiliki sifat-sifat yang lebih unggul dibandingkan dengan beton normal, keunggulan beton mutu tinggi dibandingkan dengan beton normal antara lain kekuatan tekan yang tinggi sehingga dimensi dari elemen struktur dapat menjadi lebih ramping. Beton mutu tinggi sudah banyak diaplikasikan dalam berbagai ragam struktur, seperti gedung bertingkat, jembatan dengan bentangan yang panjang, bendungan, dermaga, terowongan, dan lain sebagainya. Beton mutu tinggi merupakan beton dengan kuat tekan lebih besar dari 41,4 Mpa. Campuran pada beton mutu tinggi mengunakan bahan tambahan seperti additive dan admixture yang bertujuan untuk mengurangi jumlah air pencampur agar didapatkan beton dengan kepadatan struktur yang tinggi sehingga memiliki kekuatan dan ketahanan yang lebih besar terhadap sulfat. Akan tetapi beton mutu tinggi memiliki berat yang lebih besar dibandingkan beton normal dan harganya relatif mahal (Cornelis, R., et.al, 2014). Salah satu cara untuk mengatasinya adalah dengan mensubsitusi proposi agregat halus dalam campuran beton dengan material yang mendukung dari segi karakteristik dan ekonomi.

Pasir pozzolan dihasilkan dari alam yaitu dari hasil sedimentasi gunung berapi yang berbentuk seperti pasir yang berwarna coklat. Pasir pozzolan ini mengandung senyawa silika dan alumina seperti yang terkandung di dalam semen sehingga diharapkan dapat meningkatkan rekatan antar partikel beton (Saleh, R, Analisis, 2009). Pasir pozzolan juga memiliki berat jenis yang lebih ringan dari pada pasir $(2,6 \mathrm{gr} / \mathrm{ml})$ yaitu sebesar $1,21 \mathrm{gr} / \mathrm{ml}$. Dilihat dari bentuk dan ukurannya yang menyurupai pasir maka pasir pozzolan diharapkan dapat digunakan sebagai substitusi agregat halus pada beton.

\section{Metode Penelitian}

Beton mutu tinggi merupakan beton yang mempunyai sifat khusus, seperti tingkat susut (shrinkage) rendah, permeabilitas rendah, modulus elastisitas tinggi, dan kuat tekan tinggi. Beton mutu tinggi umumnya memiliki faktor air semen yang rendah dengan rentang 0,2-0,35. Semakin rendah FAS, maka porositas beton juga cenderung rendah, sehingga pekerjaan beton menjadi sangat sulit, pemadatannya tidak maksimal dan beton menjadi keropos, hal ini menyebabkan berkurangnya kuat tekan beton. Cara mengatasi hal tersebut dapat digunakan

Pengaruh Substitusi Pasir Pozzolan Sebagai Agregat Halus Terhadap Kuat Tekan Beton Pasca Bakar Dengan Dan Tanpa Perendaman - Syarifah Asria Nanda, David 
superplasticizer yang sifatnya dapat mengurangi air (dengan mengunakan FAS yang kecil) tetapi tetap mudah dikerjakan.

Beton mutu tinggi (high strength concrete) yang tercantum dalam SNI 036468-2000 (Pd T-18-1999-03) didefinisikan sebagai beton yang mempunyai kuat tekan yang disyaratkan lebih besar sama dengan 41,4 MPa.

Pasir Pozzolan merupakan bahan yang mengandung senyawa silika alumina, yang tidak mempunyai sifat mengikat seperti semen akan tetapi dengan bentuknya yang halus dan dengan adanya air, maka senyawa-senyawa tersebut akan bereaksi dengan kalsium hidroksida pada suhu normal membentuk senyawa kalsium silikat hidrat dan kalsium hidrat yang bersifat hidraulis (Pujianto, A, 2011).

Standar mutu pasir pozzolan telah diatur dalam ASTM C 618-03 yang dibedakan menjadi tiga kelas :

\section{Kelas N}

Pozzolan alam atau hasil pembakaran pozzolan alam, yang dapat digolongkan ke dalam jenis seperti: tanah diatomic, opaline cherts, shales, tuff, abu terbang vulkanik atau punicite. Semuanya bisa diproses melalui pembakaran atau tanpa pembakaran.

\section{Kelas C}

Pasir pozzolan mengandung $\mathrm{CaO}$ diatas $10 \%$ yang dihasilkan dari pembakaran ligniteatau sub-bitumen batu bara.

\section{Kelas F}

Pasir pozzolan mengandung $\mathrm{CaO}$ kurang dari $10 \%$ yang dihasilkan dari pembakaran anthracite atau bitumen batu bara.

Menurut Mulyono T (2004), bila pasta semen dipanasi, dari suhu kamar sampai sekitar $200^{\circ} \mathrm{C}$, kekuatannya tampak sedikit meningkat, karena ketika sedikit di atas $100^{\circ} \mathrm{C}$ air bebas serta air yang terserap dalam pasta menguap, selanjutnya ketika jauh di atas $100^{\circ} \mathrm{C}$ air yang secara kimiawi terkait erat dalam pasta juga menguap. Selanjutnya panas dinaikkan lagi kekuatan beton menurun. Pada suhu antara $400-600^{\circ} \mathrm{C}$ kalsium hidroksida $\mathrm{Ca}(\mathrm{OH}) 2$ berubah komposisi menjadi kalsium oksida $\mathrm{CaO}+\mathrm{H}_{2} \mathrm{O}$ yang sama sekali tidak mempunyai kekuatan. Selanjutnya di atas suhu $600^{\circ} \mathrm{C}$ atau $700^{\circ} \mathrm{C}$ unsur hasil hidrasi yang lain berubah komposisi sehingga kekuatan beton kehilangan kekuatan sama sekali.

Menurut SNI 03-1974-1990, Kuat tekan beban beton adalah besarnya beban per satuan luas, yang menyebabkan benda uji beton hancur bila dibebani dengan gaya tekan tertentu, yang dihasilkan oleh mesin tekan. Rumus yang digunakan untuk perhitungan kuat tekan beton adalah:

$$
f^{\prime} c=\frac{P}{A}
$$

Keterangan:

$$
\begin{aligned}
& f^{\prime} c=\text { Kuat tekan }\left(\mathrm{N} / \mathrm{mm}^{2}\right) \text { atau }(\mathrm{MPa}) \\
& \mathrm{P}=\text { Gaya tekan }(\mathrm{N}) \\
& \mathrm{A}=\text { Luas bidang permukaan }\left(\mathrm{mm}^{2}\right)
\end{aligned}
$$

Pengaruh Substitusi Pasir Pozzolan Sebagai Agregat Halus Terhadap Kuat Tekan Beton Pasca Bakar Dengan Dan Tanpa Perendaman - Syarifah Asria Nanda, David Sarana, M. Zainul Yaqin 
Tahapan pelaksanaan mencakup persiapan alat dan bahan, pemeriksaan karakteristik material, penyediaan benda uji mencangkup (perencanaan campuran, pembuatan adukan beton, dan pemeriksaan nilai slump pada beton), pengujian (pembakaran dan uji kuat tekan) dan analisis data (Alkhaly, Yulius, R, 2014).

Bahan dan proporsi campuran pada beton meliputi agregat kasar, agregat halus, air, semen, pasir pozzolan dan superplasticizer. Variasi campuran yang digunakan adalah:

- Pasir Pozzolan : 0\%, dan 10\%

- Superplasticizer : $1,5 \%$

Pasir pozzolan yang digunakan dalam penelitian ini diambil dari desa Beurandeh Kecamatan Mesjid Raya-Ujong Bate, Aceh Besar. Pasir pozzolan yang digunakan terdiri dari butiran lolos saringan No 2 atau sehingga diperoleh diameter maksimum pasir pozzolan sebesar $2,38 \mathrm{~mm}$. Pasir pozzolan yang digunakan sebagai pengisi sebagian pasir.

Semen yang digunakan adalah semen PPC yaitu semen andalas, Superplasticizer, Agregat kasar, Agregat halus, dan Air didapatkan dari Laboratorium Teknik Sipil Universitas Malikussaleh.

Jumlah benda uji yang akan dibuat sebanyak 50 sampel dengan benda uji silinder ukuran $100 \mathrm{~mm}$ x $200 \mathrm{~mm}$, dan perendaman dilakukan 28 hari. Kemudian dilakukan pengujian kuat tekan beton setelah perendaman selama 28 hari menurut SNI 03-2834-2000 sebanyak 50 sampel. Dan kemudian beton dilakukan pembakaran pada suhu $200^{\circ} \mathrm{C}$ sebanyak 20 sampel, pada suhu $400^{\circ} \mathrm{C}$ sebanyak 20 sampel. Untuk komposisi campuran dan kode benda uji diperlihatkan seperti pada Tabel 1.

Pembuatan benda uji dimulai dengan memasukkan satu persatu material pembentukan beton seperti superplasticizer, air, semen, pasir pozzolan, agregat kasar dan halus. Hal tersebut dilakukan supaya campuran beton teraduk dengan merata dan dapat menghasilkan beton yang baik. Pengadukan beton ini dengan menggunakan molen (concrete mixer) dengan jangka waktu pengadukan kurang lebih selama \pm 20 menit. Adukan beton dimasukkan kedalam benda uji silinder yang telah diolesi dengan oli, untuk tiap lapisan dianjurkan dipadatkan dengan tongkat pemadat. Setelah selesai kemudian meratakan permukaannya dengan sendok semen. Pada saat benda uji berumur 24 jam cetakan dibuka, selanjutnya dilakukan perawatan dengan menempatkan benda uji kedalam bak air yang telah disediakan.

Tabel 1 Variasi dan jumlah benda uji

\begin{tabular}{cccccccc}
\hline No & $\begin{array}{c}\text { Klasifikasi } \\
\text { Beton }\end{array}$ & $\begin{array}{c}\text { Variasi } \\
\text { PZ }\end{array}$ & $\begin{array}{c}\text { Variasi } \\
\text { SP }\end{array}$ & & $\begin{array}{c}\text { Variasi } \\
\text { Suhu }\end{array}$ & $\begin{array}{c}\text { Umur } \\
\text { Pengujian }\end{array}$ & $\begin{array}{c}\text { Total } \\
\text { Pengujian }\end{array}$ \\
\hline 1 & $\begin{array}{l}\text { BN1, BN2, } \\
\text { BN3, BN4, } \\
\text { BN5 }\end{array}$ & $0 \%$ & $1,5 \%$ & - & - & 28 hari & 5 \\
\hline
\end{tabular}

Pengaruh Substitusi Pasir Pozzolan Sebagai Agregat Halus Terhadap Kuat Tekan Beton Pasca Bakar Dengan Dan Tanpa Perendaman - Syarifah Asria Nanda, David 


\begin{tabular}{|c|c|c|c|c|c|c|c|}
\hline 2 & $\begin{array}{l}\text { BNP11, } \\
\text { BNP12, } \\
\text { BNP13, } \\
\text { BNP14, } \\
\text { BNP15 }\end{array}$ & $10 \%$ & $1,5 \%$ & - & - & 28 hari & 5 \\
\hline 3 & $\begin{array}{l}\text { BNBTR21, } \\
\text { BNBTR22, } \\
\text { BNBTR23, } \\
\text { BNBTR24, } \\
\text { BNBTR25 }\end{array}$ & $0 \%$ & $1,5 \%$ & 5 & 5 & 28 hari & 10 \\
\hline 4 & $\begin{array}{l}\text { BPBTR31, } \\
\text { BPBTR32, } \\
\text { BPBTR33, } \\
\text { BPBTR34, } \\
\text { BPBTR35 }\end{array}$ & $10 \%$ & $1,5 \%$ & 5 & 5 & 28 hari & 10 \\
\hline 5 & $\begin{array}{l}\text { BNBDP41, } \\
\text { BNBDP42, } \\
\text { BNBDP43, } \\
\text { BNBDP44, } \\
\text { BNBDP45 }\end{array}$ & $0 \%$ & $1,5 \%$ & 5 & 5 & $\begin{array}{c}28 \text { hari }+ \\
14 \text { hari }\end{array}$ & 10 \\
\hline 6 & $\begin{array}{l}\text { BPBDP51, } \\
\text { BPBDP52, } \\
\text { BPBDP53, } \\
\text { BPBDP54, } \\
\text { BPBDP55 }\end{array}$ & $10 \%$ & $1,5 \%$ & 5 & 5 & $\begin{array}{c}28 \text { hari }+ \\
14 \text { hari }\end{array}$ & 10 \\
\hline & Jumla & da Uji & \multicolumn{4}{|c|}{ Total } & 50 \\
\hline
\end{tabular}

Pembakaran Beton dilakukan setelah selesai masa perawatan beton selama 28 hari, proses pembakaran beton dilakukan dengan cara dibakar langsung dengan api (Astari, N, 2015). Jumlah benda uji yang dibakar sebanyak 40 sampel, 20 sampel pada suhu $200^{\circ} \mathrm{C}$ dan 20 sampel pada suhu $400^{\circ} \mathrm{C}$.

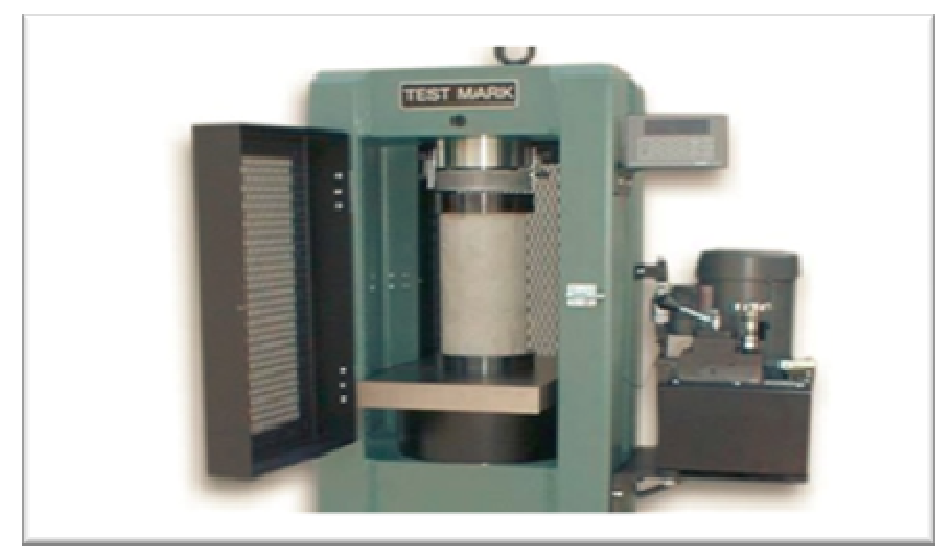

Gambar 1 Posisi pengujian kuat tekan beton

Pengaruh Substitusi Pasir Pozzolan Sebagai Agregat Halus Terhadap Kuat Tekan Beton Pasca Bakar Dengan Dan Tanpa Perendaman - Syarifah Asria Nanda, David Sarana, M. Zainul Yaqin 
Durasi waktu pembakaran tergantung pada suhu yang dicapai, setelah benda uji dibakar kemudian dibiarkan selama 24 jam di dalam ruangan. Sebanyak 10 sampel benda uji pada suhu $200^{\circ} \mathrm{C}$ dan 10 sampel benda uji pada suhu $400^{\circ} \mathrm{C}$ dilakukan pengujian kuat tekan, sedangkan sisanya 10 sampel benda uji pada suhu $200^{\circ} \mathrm{C}$ dan 10 sampel benda uji pada suhu $400^{\circ} \mathrm{C}$ dilakukan perendaman selama 14 hari kemudian dibiarkan selama 24 jam di dalam ruangan kemudian diuji kuat tekannya. Posisi pengujian diperlihatkan pada Gambar 1.

\section{Hasil dan Pembahasan}

Pengujian terhadap agregat yang dilakukan dalam penelitian ini meliputi pengujian specific gravity, absorbsi,bulk density, modulus kehalusan dan gradasi agregat. Hasil perhitungannya dirangkum dalam Tabel 2.

Tabel 2 Hasil pemeriksaan sifat fisis agregat

\begin{tabular}{lccc}
\hline \multirow{2}{*}{\multicolumn{1}{c}{ Jenis Pengujian }} & \multicolumn{3}{c}{ Jenis Agregat } \\
\cline { 2 - 4 } & Batu Pecah & Pasir & Pasir Pozzolan \\
\hline BJ SSD $\left(\mathrm{gr} / \mathrm{cm}^{3}\right)$ & 2,360 & 1,727 & 2,178 \\
\hline BJ OD $\left(\mathrm{gr} / \mathrm{cm}^{3}\right)$ & 2,286 & 2,532 & 2,014 \\
\hline Absorpsi $(\%)$ & 3,268 & 2,285 & 7,837 \\
\hline Berat Volume Padat $\left(\mathrm{gr} / \mathrm{cm}^{3}\right)$ & 1,394 & 1,556 & 1,167 \\
\hline Kadar Air $(\%)$ & 0.874 & 1,937 & 3,413 \\
\hline
\end{tabular}

Setelah dilakukan pembuatan dan perawatan benda uji, selanjutnya dilakukan pengujian kuat tekan benda uji. Pengujian kuat tekan beton dilakukan pada benda uji umur 28 hari dengan kuat tekan rencana (f'c) sebesar $42 \mathrm{MPa}$ sebanyak 50 sampel, yang terdiri dari 2 variasi. Untuk masing-masing variasi dibuat 5 sampel.

Tabel 3 Hasil pengujian kuat tekan beton

\begin{tabular}{ccc}
\hline NO & \multirow{2}{*}{ KODE } & $\begin{array}{c}\text { f'c } \\
\text { RERATA (Mpa) }\end{array}$ \\
\hline 1 & BN & 42.04 \\
\hline 2 & BNBTR $\left(200^{\circ} \mathrm{C}\right)$ & 43.06 \\
\hline 3 & BNBTR $\left(400^{\circ} \mathrm{C}\right)$ & 31.97 \\
\hline 4 & BNBDP $\left(200^{\circ} \mathrm{C}\right)$ & 43.44 \\
\hline 5 & BNBDP $\left(400^{\circ} \mathrm{C}\right)$ & 31.97 \\
\hline 6 & BP & 42.80 \\
\hline 7 & BPBTR $\left(200^{\circ} \mathrm{C}\right)$ & 44.20 \\
\hline 9 & BPBTR $\left(400^{\circ} \mathrm{C}\right)$ & 38.73 \\
\hline 10 & BPBDP $\left(200^{\circ} \mathrm{C}\right)$ & 45.10 \\
\hline
\end{tabular}

Pengaruh Substitusi Pasir Pozzolan Sebagai Agregat Halus Terhadap Kuat Tekan Beton Pasca Bakar Dengan Dan Tanpa Perendaman - Syarifah Asria Nanda, David Sarana, M. Zainul Yaqin 
Hasil hitungan kuat tekan benda uji beton silinder secara komprehensif diperlihatkan pada Tabel 3, menunjukkan hasil kuat tekan beton mengunakan substitusi pasir pozzolan pada perlakuan normal rata-rata sebesar 42,80 Mpa sedangkan pasca bakar suhu $200^{\circ} \mathrm{C}$ tanpa perendaman sebesar 44,20 Mpa serta pada suhu $200^{\circ} \mathrm{C}$ dengan perendaman sebesar $45,10 \mathrm{Mpa}$. Pada suhu $400^{\circ} \mathrm{C}$ tanpa perendaman sebesar 38,73 Mpa sedangkan pada suhu $400^{\circ} \mathrm{C}$ dengan perendaman sebesar 38,85 Mpa. Beton normal kuat tekan rata- rata sebesar 42,04 Mpa, untuk pasca bakar suhu $200^{\circ} \mathrm{C}$ tanpa perendaman sebesar $43,06 \mathrm{Mpa}$ dan pada suhu $200^{\circ} \mathrm{C}$ dengan perendaman sebesar 43,44 Mpa. Beton pasca bakar pada suhu $400^{\circ} \mathrm{C}$ tanpa perendaman sebesar 31,97 Mpa dan pada suhu $400^{\circ} \mathrm{C}$ dengan perendaman sebesar 31,97 Mpa.

Berdasarkan hasil yang diperoleh bahwa pengaruh mutu beton yang terbesar terdapat pada beton substitusi pasir pozzolan $10 \%$ pasca bakar $200^{\circ} \mathrm{C}$ dengan perendaman yaitu meningkat 3,06 Mpa dibandingkan beton normal. Sedangkan mutu beton yang terendah terdapat pada beton normal pasca bakar $400^{\circ} \mathrm{C}$ dengan dan tanpa perendaman dengan penurunan sebesar 10,06 Mpa dibandingkan beton normal.

Dari hasil pengujian dapat diperbandingkan kuat tekan beton pasca bakar dengan dan tanpa perendaman dengan variasi pasir pozzolan $10 \%$ diperlihatkan pada Gambar 2.

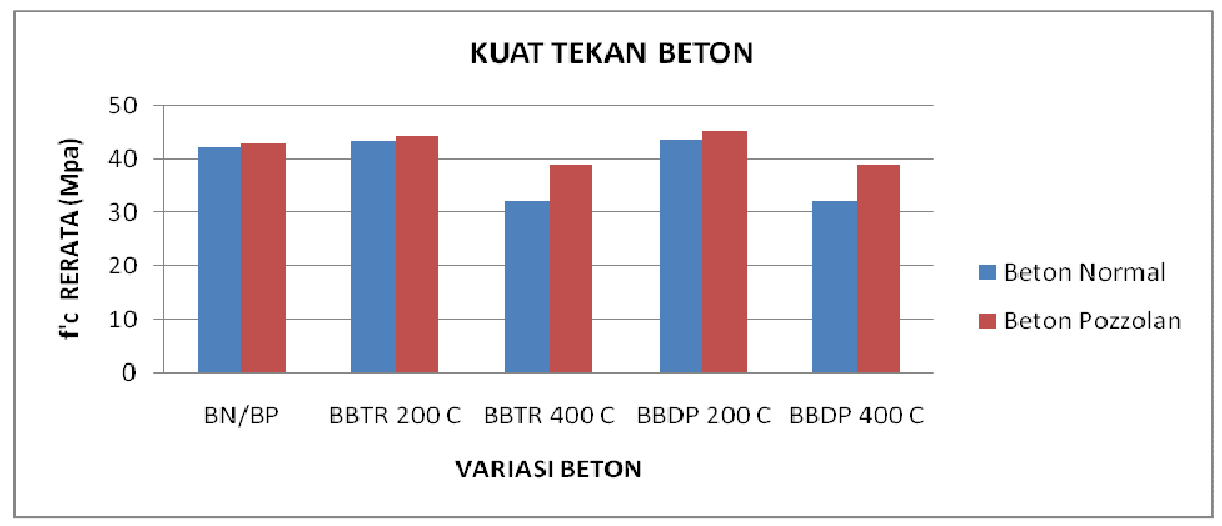

Gambar 2 Grafik kuat tekan beton

Dengan penambahan Pasir Pozzolan sebesar 10\% dari agregat halus kekuatannya tampak sedikit meningkat, pada beton yang dibakar degan suhu $200^{\circ} \mathrm{C}$ kekuatannya meningkat dibandingkan dengan beton yang dibakar dengan suhu $400^{\circ} \mathrm{C}$ yang kekuatannya menurun. Untuk beton yang direndam setelah proses pembakaran tampak meningkat kekuatannya, hal tersebut dikarenakan peremdaman selama 14 hari mampu memberikan tingkat pemulihan kuat tekan beton secara optimum.

Dari hasil penelitian dapat dihitung persentase penurunan atau kenaikan kekuatan tekan beton pasca bakar dengan dan tanpa perendaman, hasil disajikan pada Tabel 4. 
Tabel 4 Perhitungan prosentase kenaikan dan penurunan mutu beton

\begin{tabular}{clcccc}
\hline No & Kode Beton & Suhu & $\begin{array}{c}\text { Prosentase } \\
(\boldsymbol{\%})\end{array}$ & $\begin{array}{c}\text { Prosentase } \\
\text { Kenaikan \& } \\
\text { Penurunan(\%) }\end{array}$ & Keterangan \\
\hline 1 & BN & - & 100 & 0.000 & Normal \\
\hline 2 & BNBTR & $200^{\circ} \mathrm{C}$ & 102.424 & 2.424 & Kekuatan Naik \\
\hline 3 & BNBTR & $400^{\circ} \mathrm{C}$ & 76.061 & -23.939 & Kekuatan Turun \\
\hline 4 & BNBDP & $200^{\circ} \mathrm{C}$ & 103.333 & 3.333 & Kekuatan Naik \\
\hline 5 & BNBDP & $400^{\circ} \mathrm{C}$ & 76.061 & -23.939 & Kekuatan Turun \\
\hline 6 & BP & - & 100.000 & 0.000 & Normal \\
\hline 7 & BPBTR & $200^{\circ} \mathrm{C}$ & 103.274 & 3.274 & Kekuatan Naik \\
\hline 8 & BPBTR & $400^{\circ} \mathrm{C}$ & 90.476 & -9.524 & Kekuatan Turun \\
\hline 9 & BPBDP & $200^{\circ} \mathrm{C}$ & 105.357 & 5.357 & Kekuatan Naik \\
\hline 10 & BPBDP & $400^{\circ} \mathrm{C}$ & 90.774 & -9.226 & Kekuatan Turun \\
\hline
\end{tabular}

Tabel 4 menunjukkan bahwa kekuatan beton menurun pada pembakaran dengan suhu $400^{\circ} \mathrm{C}$ dengan persentase $76,061 \%$, dan kekuatan beton meningkat pada pembakaran $200^{\circ} \mathrm{C}$ dengan persentase $105,375 \%$. Sebagaimana diperlihatkan pada Gambar 3.

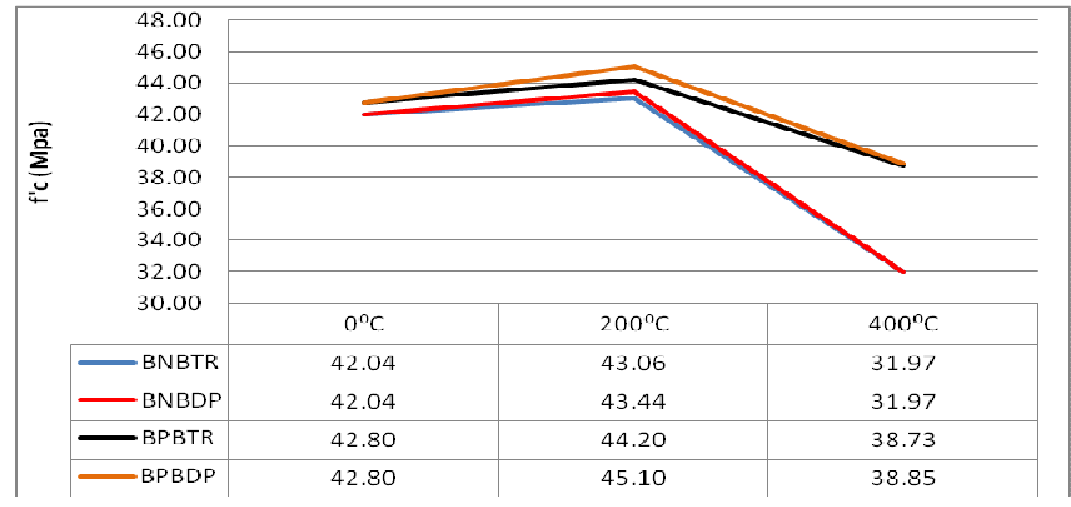

Gambar 3. Kenaikan dan Penurunan Mutu Beton

Dari hasil penelitian menunjukkan bahwa substitusi pasir pozzolan $10 \%$ dari agregat halus kekuatan pada beton dapat sedikit meningkat, adapun hasil kuat tekan yang terbesar terdapat pada beton substitusi pasir pozzolan $10 \%$ pasca bakar $200^{\circ} \mathrm{C}$ dengan perendaman yaitu rata-rata 45,10 Mpa. Sedangkan untuk nilai kuat tekan terendah yaitu terdapat pada beton normal pasca bakar $400^{\circ} \mathrm{C}$ dengan dan tanpa perendaman sebesar 31,97 MPa. Peningkatan nilai kuat tekan disebabkan karena ketika sedikit di atas $100^{\circ} \mathrm{C}$ air bebas serta air yang terserap dalam pasta menguap, selanjutnya ketika jauh di atas $100^{\circ} \mathrm{C}$ air yang secara kimiawi terkait erat dalam pasta juga menguap. Penurunan kuat tekan yang terjadi dikarenakan bila panas pada suhu antara $400-600^{\circ} \mathrm{C}$ kalsium hidroksida $\mathrm{Ca}(\mathrm{OH})_{2}$ berubah komposisi menjadi kalsium oksida $\mathrm{CaO}+\mathrm{H}_{2} \mathrm{O}$ yang sama sekali tidak mempunyai 
kekuatan (Nugraha, P. dan Antonim, 2007). Dengan adanya Substitusi 10\% pasir pozzolan dari sebagian agregat halus dan penambahan 1,5\% superplasticizer dari berat semen pada campuran beton dapat meningkatkan kuat tekan beton. Secara umum, partikel semen dalam air cenderung untuk berkohesi satu sama lainnya dan partikel semen akan menggumpal (Marthin, D, 2014).

Dengan menambahkan superplasticizer, partikel semen ini akan saling melepaskan diri. Dengan kata lain dapat menurunkan viskositas pasta semen, sehingga pasta semen lebih fluid/alir. Hal ini menunjukkan bahwa penggunaan air dapat diturunkan dengan penambahan superplasticizer, dan dapat memberikan sumbangan yang lebih efektif pada kinerja beton, terutama untuk beton bermutu tinggi. Dan dapat membuat beton lebih padat karena rongga antara butiran agregat diisi oleh pasir pozzolan sehingga dapat memperkecil pori-pori yang ada.

\section{Kesimpulan dan Saran}

\subsection{Kesimpulan} berikut:

Dari penelitian yang sudah dilaksanakan dapat diambil kesimpulan sebagai

1. Hasil penelitian menunjukkan bahwa substitusi pasir pozzolan $10 \%$ dari agregat halus kekuatan pada beton dapat sedikit meningkat, adapun hasil kuat tekan yang terbesar terdapat pada beton substitusi pasir pozzolan $10 \%$ pasca bakar $200^{\circ} \mathrm{C}$ dengan perendaman yaitu rata-rata 45,10 Mpa. Sedangkan untuk nilai kuat tekan terendah yaitu terdapat pada beton normal pasca bakar $400^{\circ} \mathrm{C}$ dengan dan tanpa perendaman sebesar 31,97 MPa.

2. Potensi/kelayakan penggunaan pasir pozzolan yaitu mutu beton meningkat dan berat jenis beton yang menggunakan pasir pozzolan lebih ringan dibandingkan dengan beton normal.

\subsection{Saran}

Adapun saran-saran untuk penelitian selanjutnya dapat diberikan sebagai berikut:

1. Hendaknya dalam pembuatan beton mutu tinggi pengerjaan harus sangat teliti.

2. Perlu dilakukan pengujian lain untuk beton dengan menggunakan substitusi pasir pozzolan seperti, hummer test atau kuat tarik lentur dan kuat tarik belah.

\section{Daftar Kepustakaan}

Alkhaly, Yulius, R, 2014, Panduan Pengujian di Laboratorium Beton dan Bahan Pembentuknya, Jurusan Teknik Sipi, Universitas Malikussaleh, Lhokseumawe.

Anonim 1, 2000, SNI 03-6429-2000 Metode Pengujian Kuat Tekan Beton Silinder, Badan Standarisasi Nasional.

Anonim 2, 2002, SNI 03-2847-2002 Tata Cara Perhitungan Struktur Beton Untuk Bangunan Gedung (Beta Version), Departemen Pekerjaan Umum Bandung.

Pengaruh Substitusi Pasir Pozzolan Sebagai Agregat Halus Terhadap Kuat Tekan Beton Pasca Bakar Dengan Dan Tanpa Perendaman - Syarifah Asria Nanda, David Sarana, M. Zainul Yaqin 
Astari, N, 2015, Pengaruh Substitusi Pasir Pozzolan Sebagai Agregat Halus Terhadap Kuat tekan, Modulus Elasrtisitas, Daktilitas, Absorpsi, dan Pola Retak Neton Mutu Tinggi, Universitas Syiah Kuala, Darussalam Banda Aceh

Mulyono, T, 2004, Teknologi Beton, Penerbit Andi, Yogyakarta

Nugraha, P. dan Antonim, 2007, Teknologi Beton, ANDI OFFSET, Yogyakarta

Pujianto, A, 2011, Beton Mutu Tinggi dengan Bahan Tambah Superplastisizer dan Fly Ash, Jurnal Ilmiah Semesta Teknik, Vol. 13, No.2, Universitas Muhammadiyah, Yogyakarta.

Cornelis, R., et.al, 2014, Kajian Kuat Tekan Beton Pasca Bakar Dengan Dan Tanpa Perendaman Berdasarkan Variasi Mutu Beton, Jurnal Ilmiah Teknik Sipil, Vol. 3, No. 2, Undana

Marthin, D, 2014, Pengujian Kuat Tekan Beton Mutu Tinggi, Jurnal Ilmiah Media Engineering. Vol. 4, No. 4, Universitas Sam Ratulangi, Manado.

Saleh, R, Analisis, 2009, Pengaruh Peningkatan Temperatur Pasca Bakar Terhadap Kuat Tekan Beton Normal, Jurnal Ilmiah Teknik Sipil, Volume 7 No. 9, Universitas Indonesia, Bogor. 